\title{
Pengaruh Stress Kerja dan Beban Kerja terhadap Turnover Intention dengan Moderasi Kepuasan Gaji
}

\author{
Safira Jingga Hernita \\ firajingga@gmail.com \\ UIN Raden Intan Lampung \\ Intan Nia Ruhyat \\ intannia013@gmail.com \\ UIN Raden Intan Lampung
}

\author{
Abdul Riduwan \\ abdulriduwan1999@gmail.com \\ UIN Raden Intan Lampung \\ Iwan Eko Ariyadi \\ iwanekoariyadi@gmail.com \\ UIN Raden Intan Lampung
}

\begin{abstract}
The occurrence of turnover is something that is not desired by the company and often results in losses for the company both in terms of costs, time and resources used. The purpose of this study is to examine the effect of work stress, workload, on turnover intention which is moderated by salary satisfaction. This research was conducted by distributing 36 questionnaires to 40 respondents who were active employees of the company who received salaries. The test was carried out with the help of statistical tools in the form of Structural Equation Modeling (SEM) based on Partial Least Square version 3 by taking into account the factor loading value $=0.6$, composite reliability with a value $=0.7$ and the variance extracted value $=0.50$. The results show that the independent variable workload has a significant positive effect on turnover intention. Likewise, the independent variable work stress also has a significant positive effect. As well as the moderating variable Salary Satisfaction weakens the relationship between workload and work stress.
\end{abstract}

Keywords : salary satisfaction, turnover intention, workload, work stress

\section{Pendahuluan}

Sumber daya manusia merupakan faktor penting yang menentukan berhasil tidaknya suatu perusahaan dalam mencapai tujuannya. Sumber daya manusia adalah aset paling berharga dan penting yang dimiliki organisasi, karena keberhasilan organisasi sangat bergantung pada faktor manusia. Untuk mencapai tujuan perusahaan, perusahaan harus memperhatikan dan memelihara karyawannya dengan baik, sehingga karyawan yang berkualitas di perusahaan tidak akan meninggalkan atau meninggalkan perusahaan (turnover intention) akibat tidak mendapat cukup perhatian dari perusahaan (Riani \& Putra, 2017). Niat keluar dari organisasi merupakan salah satu kelemahan organisasi, dapat dikatakan bahwa niat keluar tersebut adalah ketidakmampuan organisasi untuk mengatur perilaku individu. Intensi turnover adalah kecenderungan atau niat karyawan untuk berhenti bekerja dari pekerjaannya secara sukarela menurut pilihannya sendiri 
(Putra, 2012). Terjadinya turnover merupakan suatu hal yang tidak dikehendaki oleh perusahaan. Turnover yang seringkali terjadi mengakibatkan kerugian perusahaan baik dari segi biaya, waktu maupun sumber daya yang digunakan, karena perusahaan perlu melatih ulang karyawan baru dan itu membutuhkan waktu yang tidak sebentar. Tahapan dari munculnya keinginan keluar dari perusahaan ketika seseorang melakukan evaluasi dari pekerjaannya, penilaian atau pengarahan pada rasa puas dan tidak puas atas pekjerjaanya, perhitungan biaya dan manfaat atas pekerjaannya dan diakhiri dengan keputusan nyata bertahan atau keluar dari pekerjaan (Firdaus, 2017).

Tingkat turnover yang tinggi akan berdampak negatif bagi organisasi, seperti ketidakstabilan dan ketidakpastian tenaga kerja yang ada, serta tingginya biaya pengelolaan sumber daya manusia, seperti biaya pelatihan karyawan hingga biaya rekrutmen dan pelatihan ulang. Oleh karna itu penulis memilih variabel turnover intention untuk melanjutkan penelitian dari (Riani \& Putra, 2017)yang menyatakan bahwa penting untuk dilakukan analisis terkait niat karyawan untuk keluar pada suatu perusahaan yang difokuskan pada lingkungan kerja non fisik. Stress kerja adalah suatu kondisi ketegangan yang menciptakan adanya ketidakseimbangan fisik dan psikis yang mempengaruhi emosi, proses berpikir, dan kondis seseorang karyawan (Rivai \& Ella, 2013). Orang-orang yang mengalami stress menjadi nervous sehingga mereka sering menjadi marah-marah, agresif, tidak dapat relaks, atau memperlihatkan sikap yang tidak kooperatif (Hasibuan, 2012). Stress bukan masalah yang di anggap remeh karena tidak hanya mengganggu kinerja sebagai karyawan, tetapi yang terburuk bisa mengganggu kondisi mental sendiri . Stres menjadi perhatian utama, karena sudah menjadi bagian dari kehidupan karyawan dan sulit untuk menghindari stres kerja.

Sedangkan beban kerja adalah beberapa kegiatan yang membutuhkan proses atau kemampuan mental yang harus diselesaikan baik secara fisik maupun psikis dalam kurun waktu tertentu (Riani \& Putra, 2017). Reaksi karyawan di bawah stres dan beban kerja yang tinggi ditandai dengan mudah tersinggung, kurang komunikasi, kelelahan mental, kehilangan spontanitas dan kreativitas, kelelahan fisik, sakit kepala, merokok berlebihan, penundaan atau penghindaran kerja. Oleh karena itu penulis akan melakukan penelitian secara kuantitaif dengan mengadaptasi penelitian empiris dari AK (2018) yang menyatakan bahwa turnover intention dipengaruhi oleh beberapa faktor seperti kepuasan kerja, stres kerja, gaya kepemimpinan, demografi, komitmen organisasional, keadilan organisasi, budaya organisasi, beban kerja serta gaji, sehingga penulis akan menganalisis dua diantaranya yaitu stress kerja dan beban kerja. Suatu ekspresi kepuasan menunjukkan seberapa banyak suatu individu mengalami kesenangan dalam konteks organisasi. Kepuasan kerja menyangkut seberapa jauh karyawan merasakan kesesuaian antara seberapa besar penghargaan yang diterima dan pekerjaannya dengan ekspektansinya mengenai seberapa besar yang seharusnya diterima. Kepuasan kerja bisa kita pahami berkaitan dengan seberapa puas seseorang dengan aspek-aspek pekerjaannya. Kepuasan kerja didefinisikan sebagai perasaan senang atau emosi positif yang diperoleh dari pengalaman kerja, yang berkenaan dengan individu, bukan kelompok dan menyangkut masa lalu, bukan masa yang akan datang (Rita Andini, 2017). Kepuasan kerja memiliki bebeapa cankupan, salah satunya yaitu kepuaan tingkat gaji yang merupakan konvergensi antara kepentingan probadi seseorang dengan apa yang diberikan oleh suatu organisasi (Ramalho Luz, Luiz de Paula, \& de Oliveira, 2018).

Kepuasan dan ketidakpuasan atas gaji yang diterima adalah fungsi dari ketidakcocokan antara apa yang dirasakan akan diterima oleh seseorang dengan berapa banyak yang diterima seseorang. Kepuasan gaji dapat memprediksi tingkat absensi dan turnover karyawan. Banyak penelitian yang menyimpulkan bahwa hubungan antara kepuasan gaji dengan intensi keluar adalah negatif (Motowildo, 1983 pada Lum et.al. 1998; Yuyetta, 2002). Oleh karena itu selanjutnya penulis akan menmabhakan variable kepuasan gaji untuk memoderasi turnover intention untuk melengkapi keterbatasan dari penelitian Andriyani (2018) bahwa dibutuhkan indikator variabel yang masuk kedalam kategori tinggi dengan menggunakan kuesioner yang lebih bervariasi terutama pada kepuasan tingkat gaji terhadap turnover intention. 


\section{Tinjauan Pustaka}

Robins (2014) mendefinisikan stress kerja sebagai reaksi siklus mental dan perbedaan tunggal bagian dari perubahan yang dipengaruhi sebab akibat dari aktivitas, selain itu stress digambarkan ketegangan terhadap perasaan yang terpengaruhi, kondisi dengan gairah yang tinggi dan cara berfikir seseorang. Stres membawa kepada suasana negatif tapi terkadang termasuk dalam suatu kondisi yang baik secara nilai, karena dapat memicu semangat dalam bekerja, pelaksanaan dan inspirasi. Beberapa menilai penekan dari faktor tingginya tanggung jawab sebagai tes positif yang meningkatkan pemenuhan jabatan dan kualitas kerja. Dalam penelitian Ihsan, Ariffin, \& Dewi (2018), Haholongan (2018), dan Sari \& Rivai (2021) menyimpulkan bahwa stress kerja berpengaruh positif terhadap turnover intention. Bahkan Robbins \& Judge (2014), Ihsan et al., (2018), Syarifudin, Minarsih, \& Seputra (2021), Falakha (2020), Tamrin (2020) dalam penelitiannya menyatakan bahwa stress kerja berpengaruh positif signifikan terhadap turnover intention. Berbeda dengan penelitian yang dilakukan oleh Lorensa, Riadi, \& Lestari (2020) yang menyatakan bahwa stress kerja berpengaruh negatif signifikan terhadap turnover intention.

\section{$\mathrm{H}_{1}$ : Stress kerja berpengaruh positif signifikan terhadap turnover intention.}

Fitriantini, Agusdin, and Nurmayanti (2019) menyatakan bahwa tuntutan tugas atau pekerjaan, lingkungan kerja, dan organisasi merupakan bagian dari beban kerja. Schultz dan Schultz dalam Fitriantini et al., (2019) menjelaskan bahwa beban kerja adalah banyaknya pekerjaan yang dilakukan pada waktu yang ada atau sulitnya pekerjaan yang harus dilakukan oleh karyawan. Munandar dalam Hardi, Suriono, \& Manurung (2019) menyatakan bahwa kondisi uraian tugas yang wajib dipenuhi dengan waktu yang sudah ditentukan bagian dari beban kerja. Solehah \& Ratnasari (2019), Udriyah, Riyadi, \& Utaminingtyas (2018), Sakul (2018), Hardi et al., (2019) dalam penelitiannya menyatakan bahwa beban kerja berpengaruh positif signifikan terhadap turnover intention. Berbeda dengan penelitian yang dilakukan oleh Ihsan et al., (2018) yang menyatakan bahwa beban kerja berpengaruh negatif signifikan terhadap turnover intention.

\section{$\mathrm{H}_{2}$ : Beban kerja berpengaruh positif signifikan terhadap turnover intention.}

Sukanti, Asiyah, and Wahono (2021) menyatakan bahwa balas jasa yang dibayar secara periodik kepada karyawan adalah gaji secara tetap serta mempunyai jaminan yang pasti. Maksudnya, gaji tetap diberikan sekalipun pekerja berhalangan untuk masuk kerja. Gaji termasuk kompensasi tetap yang dipenuhi kepada posisi klerek, pimpinan dan pemangku jawabatan lainnya atas dasar yang teratur seperti mingguan, bulanan, dan tahunan. Kepuasan gaji sama dengan terpuaskannya seseorang atas gajinya ketika sesuai dengan apa yang diharapkan.

Perlunya rasa keadilan (equity) yang harus dirasakan individu terhadap gaji yang diterimanya atas pekerjaan yang telah dilakukan. Mukti \& Andriyani (2018), Hermawan (2018), Pratiwi (2020), Purnama (2018), dan Maharani, Rahardja, \& Edy (2018) dalam penelitiannya menyatakan bahwa kepuasan gaji berpengaruh negatif signifikan terhadap turnover intention. Berbeda dengan penelitian yang dilakukan oleh Husaini (2020) dan Arianti \& Triyanto (2020) yang menyatakan bahwa kepuasan gaji berpengaruh sampai positif signifikan terhadap turnover intention.

$\mathrm{H}_{3}$ : Kepuasan tingkat gaji berpengaruh negatif signifikan terhadap turnover intention

\section{$\mathrm{H}_{4}$ : Kepuasan tingkat gaji memperlemah hubungan antara beban kerja dan stress kerja terhadap turnover intention}




\section{Kerangka Konseptual}

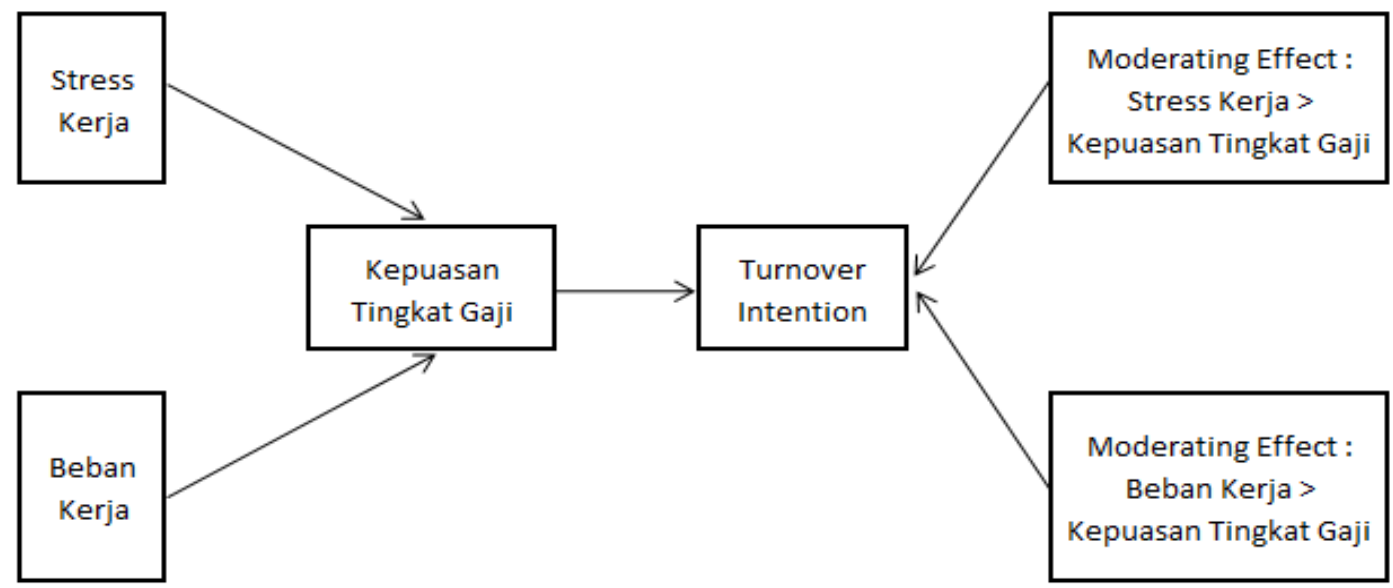

\section{Gambar 1 KerangkaKonseptual}

\section{Metode Penelitian}

Peneliti menggunakan metode pendekatan secara kuantitatif dalam penelitian ini. Metode kuantitatif adalah metode yang digunakan pada pada populasi atau sample tertentu, pengumpulan data menggunakan instrument penelitian, analisis data bersifat kuantitatif dengan tujuan untuk menguji hipotesis yang telah ditetapkan (Sugiyono, 2012). Penelitian ini menggunakan bantuan instrumen kuesioner yang dilakukan secara crossectional atau pada satu waktu tertentu. Adapun skala yang digunakan adalah skala likert yaitu ukuran skala penilaian secara berjenjang. Teknik sampel yang digunakan adalah purposive sampling yang melakukan penelitian terhadap sekelompok subjek dengan cicri-ciri tertentu atau dipandang bersangkutan erat terhadap ciri-ciri populasi yang diketahui sebelumnya.

Pengujian statistik dalam penelitian ini dilakukan dengan bantuan alat statistik Structuran Equation Modelling (SEM) berbasis Partial Least Square versi 3. Uji validitas digunakan untuk mengukur sah atau tidaknya item indukator dalam sebuah kuesioner. Uji validitas dalam penelitian ini menggunakan convergent validity dengan melihat nilai minimum indikator factor loading masing-masing item indikator $\geq 0,6$ (Sarwono, 2016). Pengujian reliabilitas selanjutnya dengan melihat nilai Cronbach's Alpha dan nilai Composite Reliability yang digunakan untuk mengukur konsistensi internal dalam uji reliabilitas data, serta nilai AVE (Average Variance Extracted) sebagai rerata persentase skor varian yang diekstrasi dari seperangkat variabel laten yang diestimasi melalui loading standardize. Untuk pengujian ini juga peneliti akan menggunakan batasan nilai Composite Reliability > 0,7 dan Cronbach's Alpha > 0,6, serta nilai AVE > 0,5 (Sarwono, 2016)

\section{Analisis Data danPembahasan}

\subsection{Analisis Data}

Pengujian model structural untuk menguji keterkaitan antara variabel, reliabilitas dan nilai $\mathrm{p}$ value. Model structural dievaluasi menggunakan uji validitas dan reliabilitas, serta signifikansi mengggunakan t statistik maupun p-value dari parameter jalur stuktural. Berdasarkan hasil uji validitas dan reliabilitas yang dilakukan menghasilkan beberapa item kuesioner yang gugur karena tidak memenuhi batas standar factor loading, sehingga pada variabel Beban Kerja (BK) tersisa 2 indikator dan Stress Kerja (SK) tersisa 3 indikator sedangkan Kepuasan Gaji (KG) dan Turnover 
Intention (TI) keduanya terdapat 3 indikator tersisa. Semua variabel dilakukan pengujian ulang sehingga semua item indikator valid dengan nilai validitas di atas $>0,6$

Tabel 1. Uji Validitas Smart PLS

\begin{tabular}{|l|l|}
\hline Uji Validitas & Factor Loading \\
\hline Indikator & 0,832 \\
\hline BK01 & 0,845 \\
\hline BK02 & 0,895 \\
\hline KG01 & 0,884 \\
\hline KG02 & 0,830 \\
\hline KG03 & 0,805 \\
\hline SK01 & 0,776 \\
\hline SK03 & 0,783 \\
\hline SK05 & 0,749 \\
\hline TI01 & 0,766 \\
\hline TI02 & 0,813 \\
\hline TI03 &
\end{tabular}

Pada uji reliabilitas nilai Composite Reliability harus memiliki nilai >0,7 dan AVE 0,5.

Tabel 2 Uji Reabilitas Smart PLS

\begin{tabular}{|c|c|c|}
\hline \multicolumn{3}{|l|}{ Uji Reliabilitas } \\
\hline Variabel & Composite Reliability & Average Variance Extracted (AVE) \\
\hline Beban Kerja & 0,826 & 0,703 \\
\hline Stress Kerja & 0,831 & 0,621 \\
\hline Kepuasan Gaji & 0,903 & 0,757 \\
\hline Turnover Intention & 0,820 & 0,603 \\
\hline
\end{tabular}

\subsection{Pembahasan}

1) Analisis pengaruh stress kerja terhadap turnover intention

Berdasarkan hasil pengujian yang telah dilakukan didapatkan hasil bahwa stress kerjaberpengaruh positif signifikan terhadap turnover intention dengan nilai p-value 0,000 $(<0,05)$ dan t hitung sebesar 3,889 lebih besar dari t tabel. Maka dapat disimpulkan bahwa hipotesis 1 didukung. Hasil tersebut mendukung penelitian dari (Sari \& Rivai, 2021)yang menyimpulkan bahwa stress kerja berpengaruh positif terhadap turnover.

2) Analisis pengaruh beban kerja teradap turnover intention Berdasarkan hasil pengujian yang telah dilakukan didapatkan hasil bahwa beban kerjaberpengaruh positif signifikan terhadap turnover intention dengan nilai p-value 0,013 $(<0,05)$ dan $t$ hitung sebesar 2,498 lebih besar dari t tabel. Maka dapat disimpulkan bahwa hipotesis 2 didukung. Hasil tersebut senada dengan penelitian(Sakul, 2018) yang menyatakan bahwa beban kerja berpengaruh positif terhadap turniver intention. 


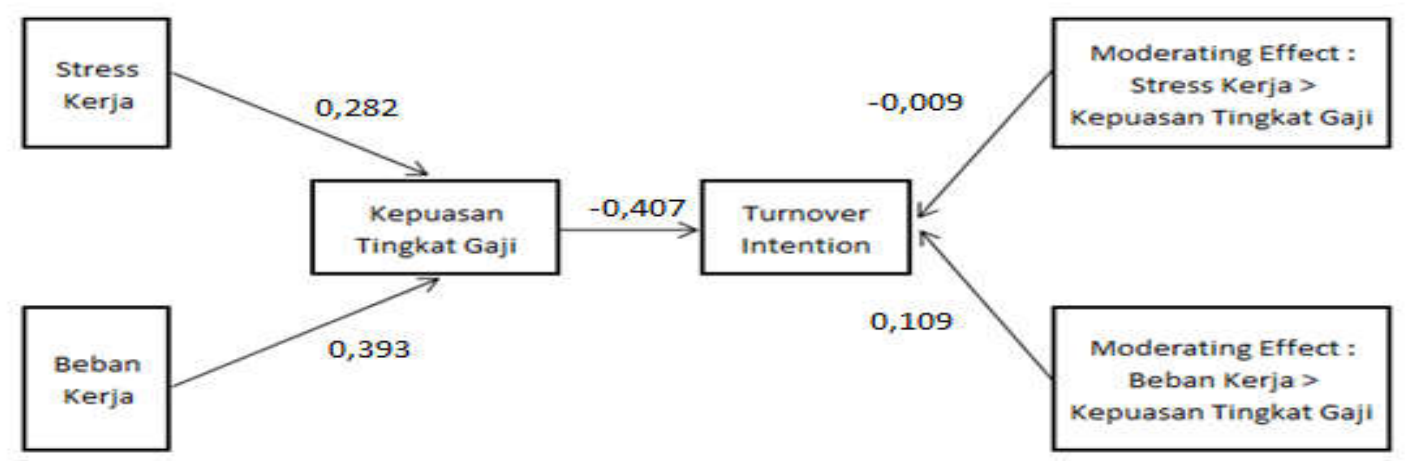

Gambar 2 Path Coefficient Smart PLS

3) Analisis kepuasan gaji terhadap turnover intention

Berdasarkan hasil pengujian yang telah dilakukan didapatkan hasil bahwa kepuasan gajiberpengaruh negatif signifikan terhadap turnover intention dengan nilai p-value 0,000 $(<0,05)$ dan path coefficient yang bernilai negatif. Maka dapat disimpulkan bahwa hipotesis 3 didukung, dan memenuhi syarat untuk dilakukan uji moderasi berdasarkan kaidah (Baron \& Kenny, 1986). Sehingga hasil analisis memperkuat penelitian (Hermawan, 2018) yang mengungkapkan bahwa kepuasan gaji berpengaruh negatif terhadap turnover intention.

Tabel 3. Path Coeficient Smart PLS

\begin{tabular}{|l|l|l|l|}
\hline & Original Sample & T Statistic & P-Values \\
\hline Beban Kerja > Turnover Intention & 0,282 & 2,498 & 0,013 \\
\hline Stress Kerja > Turnover Intention & 0,393 & 3,889 & 0,000 \\
\hline Kepuasan Gaji > Turnover Intention & $-0,407$ & 3,629 & 0,000 \\
\hline Moderating BK*KG > Turnover Intention & 0,109 & 0,571 & 0,568 \\
\hline Moderating SK*KG > Turnover Intention & $-0,009$ & 0,058 & 0,954 \\
\hline
\end{tabular}

4) Analisis kepuasan gaji memoderasi variabel beban kerja dan stress kerja terhadap turnover intention

Uji moderating effect kepuasan gaji terhadap turnover intention dengan variabel independen beban kerja mendapatkan nilai p-value 0,568 dari yang uji variabel langsung sebelumnya p- value bernilai segnifikkan 0,013. Sedangkan uji moderating effect kepuasan gaji terhadap turnover intention dengan variabel independen stress kerja mendapatkan nilai p-value 0,954 dari yang uji variabel langsung sebelumnya p- value bernilai segnifikan 0,013 . Maka dapat disimpulkan bahwa Hipotesis 4 didukung, yaitu variabel kepuasan gaji memperlemah hubungan stress kerja dan beban kerja terhadap turnover intention.

Tabel 4 Hasil Hipotesis

\begin{tabular}{|l|l|l|}
\hline No & Item & Hasil \\
\hline 1 & Hipotesis 1 & Terdukung \\
\hline 2 & Hipotesis 2 & Terdukung \\
\hline 3 & Hipotesis 3 & Terdukung \\
\hline 4 & Hipotesis 4 & Terdukung \\
\hline
\end{tabular}

\section{Kesimpulan}

Berdasarkan hasil uji validitas, uji reliabilitas, uji hipotesis dan moderating effect didapatkan bahwa variabel independen beban kerja berpengaruh positif signifikan terhadap turnover intention karena p-value $(0,013<0,050)$. Begitu juga variabel independen stress kerja yang juga berpengaruh positif signifikan karena p-value $(0,000<0,050)$. Serta variabel moderasi Kepuasan Gaji memperlemah hubungan beban kerja dan stress kerja karena nilai p-value yang 
mulanya 0,013 meningkat menjadi 0,954 untuk beban kerja, sedangkan untuk variabel stress kerja p-value yang mulanya 0,000 menjadi 0,954 .

Berdasarkan hasil analisis yang dilakukan, maka penulis memberikan beberapa saran yang dapat dikemukakan dalam penelitian ini adalah sebagai berikut :

1) Perusahaan swasta untuk lebih memperhatikan stress kerja dan beban kerja yang dirasakan karyawannya untuk menghindari cycle turnover.

2) Dalam penelitian ini, penulis hanya melakukan penelitian terhadap karyawan yang bekerja di lingkungan non-fisik pada perusahaan swasta. Sehingga penelitian selanjutnya disarankan melakukan penelitian dari sisi bagian lainnya.

\section{Daftar Pustaka}

AK, B. (2018). Turnover Intention Influencing Factors of Employees: An Empirical Work Review. Journal of Entrepreneurship \& Organization Management, 07(03), 23-31. https://doi.org/10.4172/2169-026x.1000253

Arianti, K., \& Triyanto, T. (2020). PENGARUH KEPUASAN ATAS GAJI DAN KOMITMEN ORGANISASI TERHADAP TURNOVER INTENTION DI RS. PKU MUHAMMADIYAH BLORA. Riset Manajemen Dan Akuntansi, 11(2), 72-92.

Falakha, A. (2020). PENGARUH STRES KERJA DAN KEPUASAN KERJA TERHADAP TURNOVER INTENTION KARYAWAN OUTSOURCING. Jurnal Ilmiah MEA (Manajemen, Ekonomi, \& Akuntansi), 4(3), 1818-1830.

Firdaus, A. (2017). Faktor-Faktor Yang Mempengaruhi Turnover Intention (Studi Pada Karyawan Perusahaan Jasa Multi Finance Di Kota Jambi). EKONOMIS: Journal of Economics and Business, 1(1), 1. https://doi.org/10.33087/ekonomis.v1i1.2

Fitriantini, R., Agusdin, A., \& Nurmayanti, S. (2019). PENGARUH BEBAN KERJA, KEPUASAN KERJA DAN STRES KERJA TERHADAP TURNOVER INTENTION TENAGA KESEHATAN BERSTATUS KONTRAK DI RSUD KOTA MATARAM. Jurnal Distribusi, 8(1), 23-38.

Haholongan, R. (2018). Stres Kerja, Lingkungan Kerja Terhadap Turnover Intention Perusahaan. Jurnal Manajemen Indonesia, 18(1).

Hardi, B., Suriono, H., \& Manurung, H. P. (2019). Pengaruh Konflik, Stres Kerja, Kepuasan Kerja, Dan Beban Kerja Terhadap Turnover Intention Karyawan Pada CV Honda Karya Utama Kisaran. Jurnal Manajemen, Ekonomi Sains, 1(1), 39-48.

Hasibuan, M. S. (2012). Manajemen Sumber Daya Manusia. In Jakarta: PT.Bumi Aksara.

Hermawan. (2018). ANALISIS PENGARUH KEPUASAN GAJI DAN BEBAN KERJA TERHADAP TURNOVER INTENTION DENGAN MEDIASI KEPUASAN KERJA PADA KARYAWAN PT. KOMIPO PEMBANGKITAN JAWA BALI (KPJB) JEPARA. Universitas Muria Kudus.

Husaini, F. (2020). PENGARUH GAJI, KEPUASAN KERJA, LINGKUNGAN KERJA, TINGKAT PENDIDIKAN, DAN BEBAN KERJA TERHADAP TURNOVER INTENTION DI SEMEN INDONESIA FOUNDATION. Universitas Muhammadiyah Gresik.

Ihsan, A. A., Ariffin, Z., \& Dewi, M. S. (2018). Pengaruh Stres Kerja Dan Beban Kerja Terhadap Turnover Intention (Studi Pada PT. Bank Syariah Mandiri, Cabang Banjarmasin).

Lorensa, D., Riadi, S. S., \& Lestari, D. (2020). Pengaruh Stress Kerja dan Kesempatan Promosi terhadap Komitmen Organisasional dan Turnover Intention Karyawan. Jurnal Bisnis Dan Manajemen, 16, 195-216.

Maharani, A. D., Rahardja, \& Edy. (2018). PENGARUH KEPUASAN GAJI, DUKUNGAN ATASAN DAN STRES KERJA TERHADAP TURNOVER INTENTION (Studi pada PT. Roda Dunia Abadi, Jakarta). Fakultas Ekonomika dan Bisnis. 
Mukti, U. W., \& Andriyani, A. (2018). Analisis Pengaruh Stres Kerja, Work Support dan Kepuasan Gaji Terhadap Turnover Intention Perawat (Studi Pada RSU Nirmala, Purbalingga). Diponegoro Journal of Management, 7(4), 459-472.

Pratiwi, G. (2020). ANALISIS PENGARUH KEPUASAN GAJI, BEBAN KERJA, DAN LINGKUNGAN KERJA TERHADAP TURNOVER INTENTION KARYAWAN (Studi pada Tenaga Kependidikan Universitas Pertamina). Universitas Mercu Buana Jakarta.

Purnama, I. (2018). Pengaruh stres kerja dan kepuasan gaji terhadap turnover itention karyawan: studi pada karyawan di rumah makan Cibening Sari Kabupaten Purwakarta. Uin Sunan Gunung Djati Bandung.

Putra, B. R. (2012). Pengaruh Job STressor Terhadap Turnover Intention Dengan Kepuasan Kerja Sebagai Variabel Pemediasi (Studi Pada Karyawan Divisi Operasional PO. Rosalia Indah) (Universitas Sebelas $\quad$ Maret SUrakarta). $\quad$ Retrieved from https://digilib.uns.ac.id/dokumen/detail/25369/Pengaruh-Job-Stressor-TerhadapTurnover-Intention-Dengan-Kepuasan-Kerja-Sebagai-Variabel-Pemediasi-Studi-PadaKaryawan-Divisi-Operasional-PO-Rosalia-Indah

Ramalho Luz, C. M. D., Luiz de Paula, S., \& de Oliveira, L. M. B. (2018). Organizational commitment, job satisfaction and their possible influences on intent to turnover. Revista de Gestão, 25(1), 84-101. https://doi.org/10.1108/rege-12-2017-008

Riani, N., \& Putra, M. (2017). PENGARUH STRES KERJA, BEBAN KERJA DAN LINGKUNGAN KERJA NON FISIK TERHADAP TURNOVER INTENTION KARYAWAN. E-Jurnal Manajemen Universitas Udayana.

Rivai, V., \& Ella, J. (2013). Sumber Daya Manusia untuk Perusahaan. In Jakarta: PT Raja Grafindo Persada.

Robbins, S. P., \& Judge, T. A. (2014). Perilaku Organisasi Edis Ke-16. Salemba.

Robins, stephen. p. (2014). Teori Budaya Organisasi. Perilaku Organisasi.

Sakul, A. (2018). Pengaruh Kepuasan Kerja, Beban Kerja Dan Komitmen Organisasi Terhadap Turnover Intention Perawat RS. Bhayangkara TK. III Manado. Jurnal Riset Bisnis Dan Manajemen Vol, 6(2), 175-184.

Sari, I. P., \& Rivai, H. A. (2021). PENGARUH PERSEPSI DUKUNGAN ORGANISASIONAL, STRESS KERJA, KOMITMEN ORGANISASIONAL, DAN KEPUASAN KERJA TERHADAP TURNOVER INTENTION. JURNAL MAKRO MANAJEMEN, 6(1), 37-50.

Sarwono, J. (2016). Membuat Skripsi, Tesis dan Disertasi dengan Partial Least Square SEM (PLS SEM). Yogyakarta: Andi Offset.

Solehah, S., \& Ratnasari, S. L. (2019). Pengaruh Gaya Kepemimpinan, Beban Kerja, Job Insecurity Terhadap Turnover Intention Karyawan PT. Federal Internasional Finance Cab Batam. Jurnal Dimensi, 8(2), 210-239.

Sugiyono. (2012). Metode Penelitian Kuantitatif, Kualitatif dan R \& D.Bandung:Alfabeta. Metode Penelitian Kuantitatif, Kualitatif Dan $R \quad \& \quad$ D.Bandung:Alfabeta. https://doi.org/10.1017/CB09781107415324.004

Sukanti, F., Asiyah, S., \& Wahono, B. (2021). Pengaruh Kepuasan Gaji, Kepuasan Kerja, Dan Komitmen Organisasional Terhadap Turnover Intention Pada PT. Bumi Menara Internusa Dampit. Jurnal Ilmiah Riset Manajemen, 10(11).

Syarifudin, A., Minarsih, M. M., \& Seputra, A. (2021). PENGARUH KEPUASAN KERJA, STRESS KERJA DAN KOMITMEN ORGANISASI TERHADAP TURNOVER INTENTION. Journal of Management, $7(1)$.

Tamrin, H. (2020). Pengaruh Kepuasan Kerja, Komitmen Efektif, Dan Stress Kerja Terhadap 
Turnover Intention Pada Pramuniaga/Pramuniagi PT Circleka Indonesia Utama Cabang Yogyakarta. EBBANK, 11(1), 43-52.

Udriyah, U., Riyadi, R., \& Utaminingtyas, R. R. B. (2018). Pengaruh Beban Kerja, Work-Family Conflict Dan Job Insecurity Terhadap Kepuasan Kerja Serta Dampaknya Terhadap Turnover Intention Di PT Binabusana Internusa Semarang. Admisi Dan Bisnis, 18(3), 163-182w. 